\title{
Early mortality and overall survival in acute promyelocytic leukemia - a single-center experience
}

\author{
Svetlana Krstevska Balkanov ${ }^{1}$, Sanja Trajkova ${ }^{1}$, Sonja Genadieva Stavric ${ }^{1}$, \\ Aleksandra Pivkova Veljanovska ${ }^{1}$, Simona Stojanovska ${ }^{1}$, Dejan Spasovski ${ }^{2}$, \\ Bozidar Kocoski ${ }^{1}$, Irina Panovska Stavridis ${ }^{1}$ \\ ${ }^{1}$ University Clinic for Hematology, Faculty of Medicine, Ss. Cyril and Methodius University in Skopje, \\ Mother Theresa 17, 1000 Skopje, Republic of North Macedonia \\ ${ }^{2}$ University Clinic for Rheumatology, Faculty of Medicine, Ss. Cyril and Methodius University in Skopje, \\ Mother Theresa 17, Skopje, Republic of North Macedonia
}

Received: June 2021; Accepted: July 2021

\begin{abstract}
Acute promyelocytic leukemia (APL) is a subtype of acute leukemia (AL) with distinct cytogenetics, clinical and biological characteristics. APL was considered as one of the most rapidly lethal forms of acute myeloblastic leukemia (AML), but recently, with the introduction of all-trans retinoic acid (ATRA) it has become the most curable subtype of AL. The main difficulty with APL is early death (ED), defined as death because of any cause within 30 days after diagnosis, and it has emerged as the most important cause of treatment failure.

Our retrospective-prospective study was realized at the University Clinic for Hematology from January 2004 until December 2020. It included 46 patients with APL, according to FAB and WHO classification with confirmed molecular diagnosis. The following patients' risk stratification factors were analyzed: age, Sanz risk score, WBC, PL, clinical presentation of the disease, levels of fibrinogen and Ddimers.

During the study period, APL was diagnosed in 46 patients, 24 females (52.2\%) and 22 males (47.8\%), with mean age of 45 years. The overall survival showed that 24 patients $(52.1 \%)$ were alive and $22(47.8 \%)$ had lethal outcome. Regarding treatment, five patients (10.9\%) died before starting the chemo-treatment. But, still, ED was observed in 13 patients (59\%), and in 9 patients (40.9\%) death occurred 30 days after establishing the diagnosis. The main reasons of mortality were also analyzed. To prevent ED prior to treatment, suspected APL patients should be immediately hospitalized and treated as medical emergency.
\end{abstract}

Keywords: acute promyelocytic leukemia, early death, all-trans retinoic acid

\section{Introduction}

Acute promyelocytic leukemia (APL) is a different subtype of acute leukemia (AL) with distinct cytogenetics, clinical and biological characteristics. APL is a rare disease; however, it has become a wellrecognized entity, characterized as the M3 subtype of acute myeloblastic leukemia (AML) within the FAB that accounts for $<10 \%$ of all AML cases, with estimated incidence of 0.1/100,000 (Bennett et al., 1976; Sant et al., 2010). Since APL is a rare disease, epidemiological data about this disease can be obtained only from large collaborative multicenter researches. The disease is characterized by a unique blast morphology, called promyelocytes, the presence of coagulopathy and

\footnotetext{
* svetlanakrstevskaa@yahoo.com
} 
fibrinolysis at the time of diagnosis, and a specific balanced reciprocal translocation $\mathrm{t}(15 ; 17)$ which fuses the promyelocyte (PML) gene on chromosome 15 to the retinoic acid receptor alpha $(\mathrm{RAR} \alpha)$ gene on chromosome 17. Variant chromosomal translocation $\mathrm{t}(11 ; 17), \mathrm{t}(5 ; 17)$ can be detected in no more than $2 \%$ of the APL patients.

In the past, APL was considered as one of the most rapidly lethal forms of AML, but recently it has become the most curable subtype of AL. Nowadays with the new treatments, APL is considered a highly curable disease with a two-year-progression and free survival rates of 75$84 \%$. Today, approximately $70-80 \%$ of patients may be cured (Sanz et al., 2008; Tallman et al., 1997). Nevertheless, APL is still a medical emergency because it requires a prompt treatment as early as possible. Treatment is initiated even prior to its cytogenetic or molecular confirmation. The high-level early mortality from APL is mostly due to hemorrhage and disseminated intravascular coagulation, fibrinolysis and proteolysis (Yanada et al., 2007). Biological features of APL account for its unique phenotype and provide potential targets for tailored treatment.

Flow cytometric immunophenotypic analysis can facilitate prompt diagnosis of APL. It is well documented that $\mathrm{CD} 2+, \mathrm{CD} 34+$, and CD56+ phenotypes are associated with lower overall survival (OS) rate, shorter remission, decreased incidence of remission, and increased incidence of early death; however, all these are considered as accessory diagnostic tools (Ahmad et al., 2012; Albano et al., 2006; Fung et al., 2014).

Regarding the treatment development, in the 1970s, (Bernard et al., 1973) APL leukemic cells were shown to be relatively sensitive to chemotherapy (CT: daunorubicin), which yielded a complete remission (CR) rate of $19(55 \%)$ in 34 patients with APL. Since then, CT composed of an anthracycline (daunorubicin, idarubicin, or others) and cytosine arabinoside (Ara-C) was the frontline treatment of APL, and the CR rates could reach $75 \%$ to $80 \%$ in newly diagnosed patients. However, the frequently observed aggravation of bleeding syndrome from CT, leading to high early death rate, necessitated intensive platelet and fibrinogen support. The new tailored treatment started in the mid-1980s when differentiating agent all-trans retinoic acid (ATRA) was discovered and arsenic trioxide (ATO) in 1996, which are known to target RAR $\alpha$ and PML, the two distinct moieties of the diseasespecific oncoprotein PML/RAR $\alpha$ (De Thé et al., 2012). The success of ATRA and ATO in APL treatment furnishes the first model of molecular target-based induction of differentiation and apoptosis, ahead of targeting therapy with imatinib mesylate for chronic myeloid leukemia (CML). The recent results have shown both high CR rates (90-94\%) and high 5-year DFS rates (90\%) using ATRA/ATO/CT in APL (Wang and Zhu Chen, 2008). With the introduction of these agents, the natural history of APL has changed, as they induce differentiation and maturation of leukemic promyelocytes to neutrophils (Asou et al., 2001; Choudhry et al., 2012; Daver et al., 2015; Karim et al., 2014).

The main difficulty with APL is early death (ED), which is defined as death because of any cause within 30 days after diagnosis, and it has emerged as the most important cause of treatment failure and obstacle to cure the majority of patients. Most of the deaths are caused by bleeding, or infection, which is the second most common etiology (Watts and Tallman, 2014). The major indicator of early death is the white blood cells (WBCs) count before treatment, and it is the only known independent risk factor that predicts prognosis for this disease in this study population (Fang et al., 2014; Mantha et al., 2017). Some other manifestations and clinical presentation of the disease include bleeding, DIC and infections, as well as low PL, low level of fibrinogen and high levels of Ddimers and Sanz risk score.

Differentiation therapy with ATRA has made a major advance and became the first-choice drug in treatment of APL. Conversion of 13-cis-retinoic acid and 9-cis-retinoic acid to ATRA is very rapid and time dependent and, hence, it is important to rapidly administer two major doses of this agent. The antiproliferative effect of ATRA appears only 24 hours after administration and induces the differentiation and maturation of promyelocytes (Siddikuzzaman et al., 2011). Large studies reported ED rates of 3-10\% (Sanz et al., 2019), while in single institutions, this percentage was higher. Patients treated with ATRA therapy had ED up to $26 \%$ (Di Bona et al., 2000).

In treatment of APL with ATRA or ATO, the differentiation syndrome (DS), represents a lifethreatening complication. It affects about $20-25 \%$ of all patients and so far, there are no definitive diagnostic criteria. Clinically, DS is characterized by weight gain, fever not attributable to infection, respiratory distress, cardiac involvement, hypotension, and/or acute renal failure. DS pathogenesis is not completely understood, but it is believed that an excessive inflammatory response is the main phenomenon involved, which results in an increased production of chemokines and expression of adhesion molecules on APL cells. Due to the high morbidity and mortality associated with DS, its recognition and prompt initiation of the treatment is of utmost importance (Rego and De Santis, 2011). Recommended management of DS is immediate administration of corticosteroids and disruption of the ATRA therapy. Once the syndrome has resolved, the steroids can be discontinued (Sanz et al., 2019).

The objectives of this study were to recognize the clinical features and possible risk factors for early mortality in APL patients and to determine the overall survival having in mind many risk factors. It was also our aim to analyze the causes of mortality of patients with APL, and to enhance the efficiency in future treatments. 


\section{Materials and methods}

This retrospective-prospective study was realized at the University Clinic for Hematology in Skopje,in the period from January 2004 until December 2020. Forty-six patients with APL were included (male - 22, female - 24), at the age ranging from 15 to 77 years (mean range 45 ).

Diagnostic criteria of APL were based on the FrenchAmerican-British classification system (FAB) and the World Health Organization Classification of Tumors Pathology and Genetics of Tumors of Hematopoietic and Lymphoid Tissues (Bennett et al., 1976; Vardiman et al., 2009).

Cytogenetic and flow cytometry were done whenever possible. Molecular diagnosis was confirmed by reverse transcription-polymerase chain reaction (RT-PCR) analysis in all of the patients and it was performed from bone marrow and peripheral blood. Patients' risk stratification was done according to Sanz risk score, which classified patients into three groups depending on their initial white blood cell (WBC) and platelet counts (Sanz et al., 2000):

- High risk: patients with $\mathrm{WBC}$ count $>10 \times 10^{9} / \mathrm{L}$, irrespective of platelet counts,

- Intermediate risk: patients with $\mathrm{WBC}$ count $\leq 10 \times$ $10^{9} / \mathrm{L}$ and platelets $40 \times 10^{9} / \mathrm{L}$ and

- Low risk: patients with $\mathrm{WBC} \leq 10 \times 10^{9} / \mathrm{L}$, but with platelet count $>40 \times 10^{9} / \mathrm{L}$.

Also, the risk stratification was done according to the level of WBCs and PLs at the time of diagnosis (Sanz et al., 2019):

- High risk: WBCs $>10 \times 10^{9} / \mathrm{L} ; \mathrm{PLs}<30 \times 10^{9} / \mathrm{L}$

- Low risk: $\mathrm{WBCs} \leq 10 \times 10^{9} / \mathrm{L} ; \mathrm{PLs}>30 \times 10^{9} / \mathrm{L}$

Patients were analyzed with regards to their clinical presentation and laboratory parameters for WBCs, PLs, levels of fibrinogen and D-dimer at the time of diagnosis.

All patients were treated with AIDA protocol (Idarubicin $12 \mathrm{mg} / \mathrm{m}^{2} /$ day given as an intravenous bolus on days 2, 4, 6 and 8 and all-trans-retinoic acid, $45 \mathrm{mg} / \mathrm{m}^{2}$ oral doses, divided into two daily doses which were maintained until complete remission). The cytarabine was added in the high-risk category patients according to WBC and clinical presentation of bleeding. Dose modification was considered in older patients with comorbidities. Only one patient was treated like refractory APL with AIDA and ATO.

A written informed consent was obtained from all patients before starting the study. All medical history data were taken from patients' record database at the University Clinic for Hematology.

\section{Statistical analysis}

Statistical analysis was performed using the SPSS software, version 22. We used the Kaplan-Mayer survival curves (cumulative proportion surviving). The following survival analyses were used in this study: percentiles of survival analysis (comparison of two samples), Log Rank test (comparison of multiple samples) and Chi-square (Descriptive statistics - median, mean of survival times).

\section{Results}

A total of 46 patients were involved in the study realized between January 2004 and December 2020. Patients' characteristics were: 24 females $(52.2 \%)$ and 22 males $(47.8 \%)$ of the total number of 46 patients, with mean age of 45 years, ranging from 15-77 years. Patients were divided into two groups: under the age of 55 (36 patients, $78.3 \%)$ and above the age of 55 years (10 patients, $21.7 \%$ ). More than two thirds of them were young adults. In our Center, a total of 646 patients with AML were diagnosed in the period from 2010 to 2020. APL was found in $34(5.3 \%)$ patients.

Of the total group of APL patients, at the end of the study period, the overall survival showed that 24 patients $(52.1 \%)$ were alive and $22(47.8 \%)$ had death outcome. Regarding the treatment, of 46 patients, five patients (10.9\%) passed away before starting the management plan and chemotherapy treatment. Therefore, 41 patients $(89.1 \%)$ received different initial induction therapy (Table $1)$.

Table 1. Outcome of patients with APL

\begin{tabular}{|c|c|c|}
\hline \multirow{2}{*}{$\begin{array}{l}\text { Total number of patients diagnosed } \\
\text { with APL }(2004 / 2020)\end{array}$} & \multicolumn{2}{|c|}{46} \\
\hline & $n^{\circ}$ & $(\%)$ \\
\hline Alive & 24 & 52.2 \\
\hline Dead & 22 & 47.8 \\
\hline $\mathrm{n}^{\circ}$ of treated patients (regimen) & 41 & 89.1 \\
\hline $\mathrm{n}^{\circ}$ of untreated patients (w/o regimen) & 5 & 10.9 \\
\hline
\end{tabular}

In the group of patients under medical regimen, a CR was observed in 30 patients $(73.1 \%), 2$ patients $(4.9 \%)$ had refractory disease (RD) and 9 patients (22\%) died during induction and consolidation treatment.

AIDA protocol received 23 patients $(56.1 \%)$, the other group of 17 patients $(41.5 \%)$ was treated with AIDA protocol and cytarabine. Only one patient $(2.4 \%)$ was treated like refractory APL with AIDA plus ATO.

Seven $(23.3 \%)$ of the patients with achieved CR developed relapse of the disease later; five of them died and 2 of them are still in remission. In the CR group of patients (30), half $(15.50 \%)$ were treated with AIDA + cytarabine and the other half with AIDA only (Table 2).

Death occurred in 22 patients, among them early death (ED) was observed in 13 patients (59\%), and in 9 patients $(40.9 \%)$ death occurred 30 days after establishing the diagnosis. 
Table 2. Outcome of patients treated with different regimens

\begin{tabular}{lcc}
\hline \hline \multirow{2}{*}{ Medical regimen used in treated patients } & \multicolumn{3}{c}{41} & \\
& $\mathrm{n}^{\circ}$ & $(\%)$ \\
\hline AIDA + Cytarabine & 17 & 41.5 \\
AIDA & 23 & 56.1 \\
AIDA + ATO & 1 & 2.4 \\
\hline Outcome & & \\
\hline CR (Complete remission) & 30 & 73.1 \\
RD (Refractory disease) & 2 & 4.9 \\
Died during the induction therapy and consolidation & 9 & 22.0 \\
\hline
\end{tabular}

CR-Complete remission in patients receiving medical regimen

\begin{tabular}{|c|c|c|c|}
\hline AIDA + Cytarabine & & 15 & 50.0 \\
\hline AIDA & & 15 & 50.0 \\
\hline \multicolumn{4}{|l|}{ Outcome } \\
\hline \multirow[t]{3}{*}{ Relapse occurance } & & 7 & 23.3 \\
\hline & *Died after relapse occurance & 5 & \\
\hline & *Alive after relapse occurance & 2 & \\
\hline
\end{tabular}

The main reasons of mortality were also analyzed. They included bleeding in CNS (13 patients, 59\%), infections (4 patients, 18.2\%), ATRA syndrome (2 patients, 9\%), 2 patients (9\%) with respiratory failure and one patient $(4.5 \%)$ with acute renal failure.

Regarding the time of death, 5 patients $(22.7 \%)$ from
ED group died prior to treatment and 8 patients during the induction period $(36.3 \%)$. Regarding the time of death after 30 days, 5 patients passed away from relapse of the disease, 2 patients died during consolidation phase and 2 of primary refractory disease (Table 3 ).

Table 3. Rate, time and causes of death

\begin{tabular}{lrc}
\hline \multicolumn{1}{c}{ Number of patients that died } & 22 & $(\%)$ \\
\hline Early death $<30$ days & $\mathrm{n}^{\circ}$ & 59.1 \\
Death > 30 days & 9 & 40.9 \\
\hline Causes of death & \multicolumn{2}{c}{22} \\
in ED patients & 13 & 59.1 \\
\hline Bleeding in CNS & 4 & 18.2 \\
Infections & 2 & 9.1 \\
ATRA syndrome & 2 & 9.1 \\
Respiratory failure & 1 & 4.5 \\
Acute renal failure & \multicolumn{2}{c}{13} \\
\hline Time of death in ED patients & 5 & 38.5 \\
\hline $\mathrm{n}^{\circ}$ of patients that died without induction therapy & 8 & 61.5 \\
$\mathrm{n}^{\circ}$ of patients that died during the induction therapy & \multicolumn{2}{c}{9} \\
\hline Causes of death in patients $>$ 30 days & 5 & 55.6 \\
\hline As a result of relapse & 2 & 22.2 \\
As a result of RD - Refractory disease & 2 & 22.2 \\
\hline During consolidation & \multicolumn{2}{c}{5} \\
\hline
\end{tabular}


Thirteen patients (out of 22) died within the first 30 days. The factors found to be significantly associated $(p<0.05)$ with early death were: age, Sanz risk score, level of $\mathrm{WBC}$, level of platelets, clinical presentation of bleeding, infection, weakness, fibrinogen and D-dimer level. The higher risk score resulted in higher early death rate. There were $7(53.8 \%)$ patients with intermediate Sanz score and 6 patients $(46.1 \%)$ were at a high risk. We found no patients with low risk in this group. The ED rate was higher (in the high-risk group (WBC > $10 \times 10^{9} / \mathrm{L}$ ) meaning $61.5 \%$ or 8 patients compared to $38.5 \%$, for the other 5 patients with low risk (WBC $<10$ x $10^{9} / \mathrm{L}$ ) ( $p<0.05)$. Regarding the platelet count high risk was observed in 11 patients $(84.6 \%)$ and low risk in 2 patients $(15.4 \%)$; all of the patients had bleeding like major clinical presentation of the disease (Table 4).

Table 4. Rate of early death (ED) by several factors

\begin{tabular}{|c|c|c|}
\hline \multirow{2}{*}{ Number of ED patients } & \multicolumn{2}{|c|}{13} \\
\hline & $n^{\circ}$ & $(\%)$ \\
\hline \multicolumn{3}{|l|}{ Age (years) } \\
\hline$<55$ & 9 & 69.2 \\
\hline$>55$ & 4 & 30.8 \\
\hline \multicolumn{3}{|l|}{ Risk factor according to Sanz score } \\
\hline Low risk & l & 0.0 \\
\hline High risk & 6 & 46.2 \\
\hline Intermediate risk & 7 & 53.8 \\
\hline \multicolumn{3}{|l|}{ WBCs 1 to $114 \times 10^{9} / L($ median 32.8$)$} \\
\hline Low risk $<10 \times 10^{9} / \mathrm{L}$ & 5 & 38.5 \\
\hline High risk $>10 \times 10^{9} / \mathrm{L}$ & 8 & 61.5 \\
\hline \multicolumn{3}{|l|}{ Platelets 0 to $57 \times 10^{9} / L($ median 18.5$)$} \\
\hline Low risk $>30 \times 10^{9} / \mathrm{L}$ & 2 & 15.4 \\
\hline High risk $<30 \times 10^{9} / \mathrm{L}$ & 11 & 84.6 \\
\hline \multicolumn{3}{|l|}{ Clinical presentation } \\
\hline Generalized weakness & 10 & 76.9 \\
\hline Bleeding & 13 & 100.0 \\
\hline Infection & 4 & 30.8 \\
\hline Fibrinogen at diagnosis $(\mathrm{mg} / \mathrm{dl})$ range & \multicolumn{2}{|c|}{$92(15-371)$} \\
\hline D-dimer $(\mathrm{mg} / \mathrm{L})$ range & \multicolumn{2}{|c|}{$21(0.3-45)$} \\
\hline
\end{tabular}

Regarding the overall survival in our group of patients during the period of 17 years, we observed that $52.5 \%$ of the APL patients survived, while the percent of mortality was $47.8 \%$. In our group $45 \%$ of the patients survived over 4000 days, having most critical days (death outcome) in the first 30 days, while $25 \%$ of the patients survived only 12.5 days. The average survival time was 1479.7 days, and the most common reason for mortality was the nature of the disease (Fig. 1).

We evaluated the overall survival time of patients in relation to the age of patients at the time of diagnosis. It is shown that $59 \%$, of the patients below 55 years of age, survive over 200 days and $29 \%$ of patients above 55 years, survive over 200 days. In both groups the mortality rate was higher in $30 \%$ of patients, in the first days.

Log-Rank Test $\quad(W W=-4.160, \quad$ Sum $=20.902$, Var $=3.6351$, Test statistic $=-2.18196, p=.02911)$ registers statistically significant difference between survival in both adult groups below and above 55 years of age. The survival median in patients above 55 years is 25 days (95\% Confidence Interval 0.000-279.1). We confirm statistically significant effect of the age on the overall survival in APL patients treated with new treatments. (Fig. 2).

The average survival in younger patients $(<55$ years $)$ was 2898 days. The average survival in patients $>55$ years was 858.4 days. The median time of survival in patients $>$ 55 years was 25 days (95\% Confidence Interval 0.000279.1) The patients < 55 years do not achieve $50 \%$ and they survive above $59 \%$ or 4500 days. There is a statistically significant effect of the age on the OS, the older the patient is, there is a worse survival outcome. (Table 5).

A total of $51 \%$ of patients with WBC $<10 \times 10^{9} / \mathrm{L}$ initially at the time of diagnosis, survived over 4000 days, in comparison to $34 \%$ of patients whose WBC was $\geq 10 \mathrm{x}$ $10^{9} / \mathrm{L}$. We analyzed the influence of the WBCs during diagnosis on overall survival in patients with APL (LogRank Test $(W W=-4.448$ Sum $=20.902$ Var=4.6953, Test statistic $=-2.05265, p=.040111)$.

In both groups, the highest death outcome was observed in the first days, $20 \%$ in the first group and $47 \%$ in the second group. These findings have confirmed the value of elevated WBC is contributing the higher death outcome. On average, patients with WBC $<10 \times 10^{9} / \mathrm{L}$ had 2821.8 survival days, while patients with $\mathrm{WBC} \geq 10$ x $10^{9} / \mathrm{L}$ had 1561.3 survival days.

Median of overall survival of patients who have $\mathrm{WBC} \geq 10 \times 10^{9} / \mathrm{L}$ is 6 days $(95 \%$ Confidence Interval 0.000-163.164). (Fig. 3).

These patients with high WBC initially should be treated more aggressively with supportive treatment and with differentiating agents such as ATRA and chemo. (Fig. 4)

A total of $21 \%$ of patients with PL $<30 \times 10^{9} / \mathrm{L}$ initially at the time of diagnosis survived for more than 1000 days compared to $65 \%$ of patients with PL > $30 \mathrm{x}$ $10^{9} / \mathrm{L}$. In both groups, the highest death outcome happened in the first 30 days, $35 \%$ in both groups of patients died after starting of treatment. Log-Rank Test $(W W=2.9332, \quad$ Sum $=20.902, \quad$ Var $=4.1198, \quad$ Test statistic $=1.445150, p=.14842$ ) didn't show a statistical difference between the two groups that showed low and high PL at the time of diagnosis. (Fig. 5). 




Fig. 1. Overall survival in all groups of patients with APL during 17 years.

Cumulative Proportion Surviving (Kaplan-Meier)

- Complete + Censored

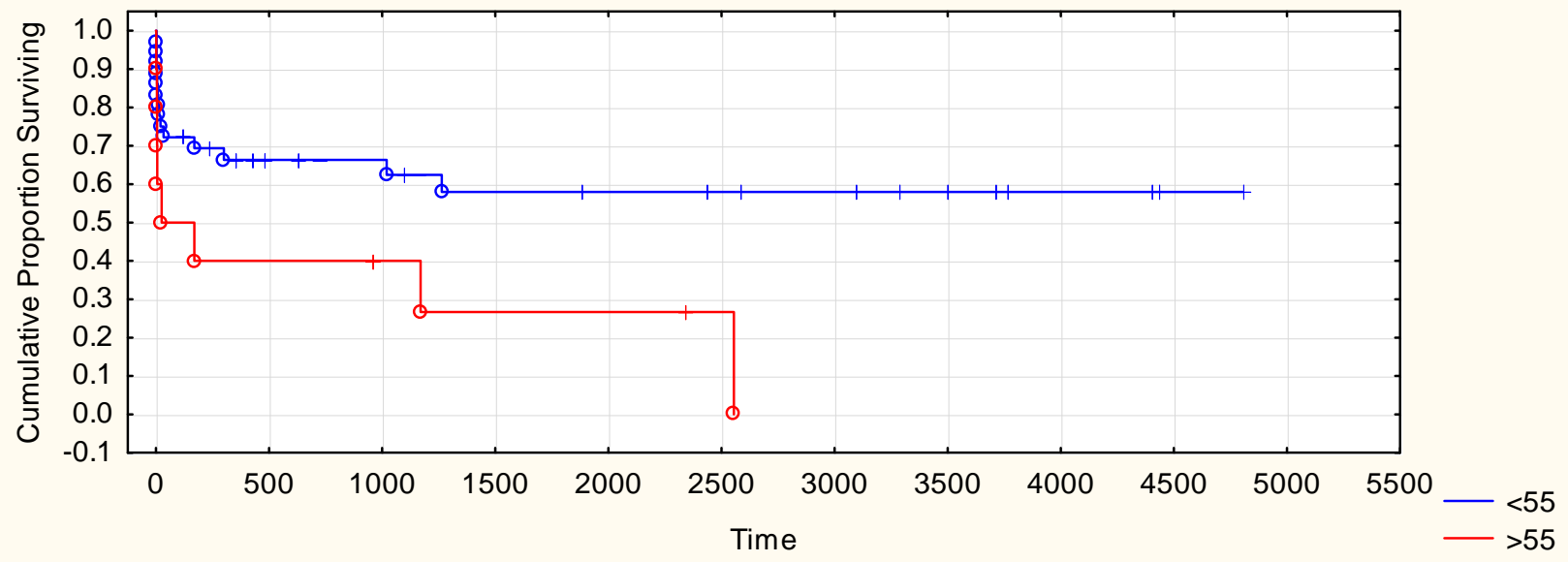

Fig. 2. Overall survival time in patients according to age.

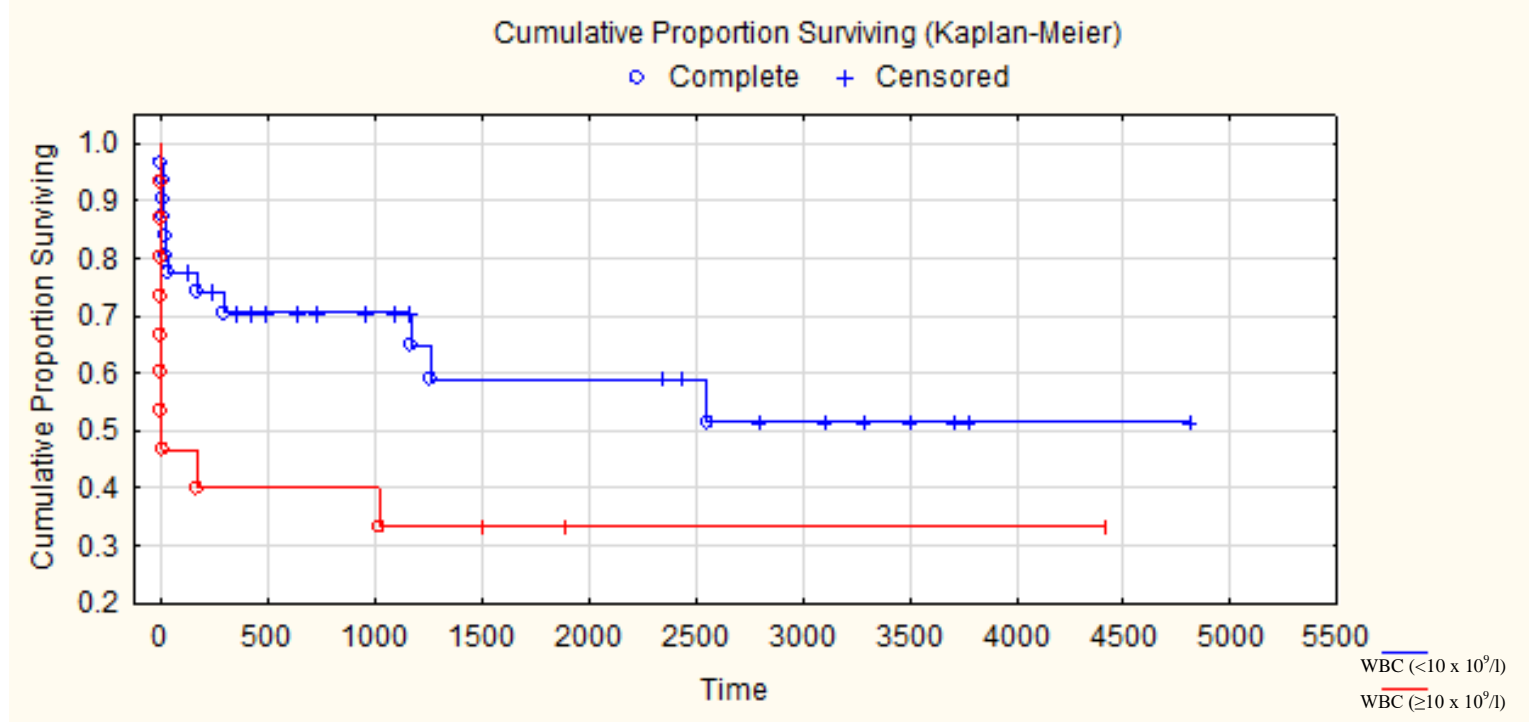

Fig. 3. Overall survival in patients with APL according to WBC. 
Table 5. Results of Log-Rank Test from survival comparison between two groups of patients (age $<55$ and $>55$ years)

\begin{tabular}{|c|c|c|c|c|c|c|c|c|}
\hline \multirow{4}{*}{ Age } & \multicolumn{8}{|c|}{ Means and Medians for Survival Time } \\
\hline & \multicolumn{4}{|c|}{ Mean $^{\mathrm{a}}$} & \multicolumn{4}{|c|}{ Median } \\
\hline & \multirow{2}{*}{ Estimate } & \multirow{2}{*}{ Std. Error } & \multicolumn{2}{|c|}{ 95\% Confidence Interval } & \multirow{2}{*}{ Estimate } & \multirow{2}{*}{ Std. Error } & \multicolumn{2}{|c|}{ 95\% Confidence Interval } \\
\hline & & & Lower Bound & Upper Bound & & & Lower Bound & Upper Bound \\
\hline$<55$ years & 2897.962 & 396.377 & 2121.063 & 3674.861 & & . & $\cdot$ & . \\
\hline$>55$ years & 858.433 & 377.392 & 118.745 & 1598.121 & 25.000 & 129.653 & .000 & 279.121 \\
\hline Overall & 2466.774 & 354.602 & 1771.755 & 3161.794 & 2555.000 & . & & . \\
\hline
\end{tabular}

Patients with PL $<30 \times 10^{9} / \mathrm{L}$ had on average 577.6 survival days, while patients with $>30 \times 10^{9} / \mathrm{L}$ had on average 2845.5 survival days.

Median survival time in patients with low PL was 300 days (95\% Confidence Interval 0.000-1054.8) (Table 6).

We also analyzed the influence of Sanz risk on overall survival of all patients with APL. 50\% of patients with Sanz risk higher survive more than 1000 days. 33\% of patients with intermediate Sanz risk survive more than 4000 days. $61 \%$ of patients with low Sanz risk survive more than 4000 days. According to Chi-square $(=8.373928, \quad d f=2, \quad p=.01520)$ there is a statistically significant difference in overall survival between the three levels of Sanz risk. (Fig 6).

On average, patients with low Sanz score survived 3270.5 days, with intermediate 1561.3 days and with high risk 688.2 days (Table 7).

\section{Discussion}

The impressive improvement in APL outcomes has recently been challenged by registry-based studies exploring APL outcomes in the real world (Park et al., 2011; Paulson et al., 2014; Thomas, 2019). These studies indicate that early mortality is currently an underestimated phenomenon in clinical trials. There is an ongoing need to decrease the early death rate (within the first 30 days from diagnosis), which is still the primary cause of treatment failure rather than the resistant disease that is so common for all other subtypes of AML (Rahmé et al., 2014).

Large clinical trials have reported an early death rate of 3-10\% (Ilnad et al., 2021; Lo-Coco et al., 2013; Sanz et al., 2010). The studies show that Sanz score, high number of white blood cells, low number of platelets, initial clinical presentation of bleeding, DIC, infections, delayed treatment at time of diagnosis are predictors for early death. An explanation for this challenge of early death is the rarity of APL coupled with the fact that the majority of APL patients in some countries are treated outside clinical trials and in smaller experienced and/or in experienced centers.

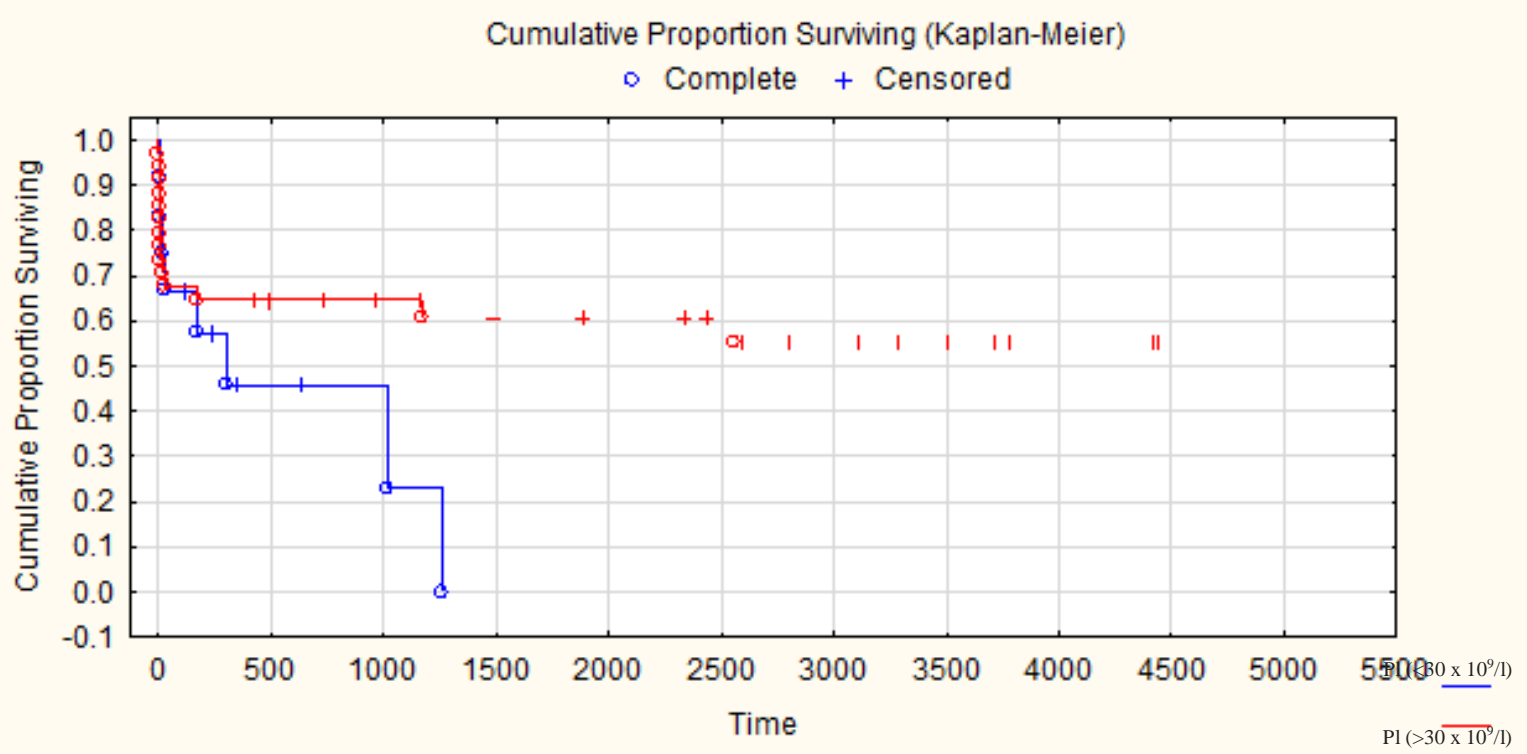

Fig. 4. Overall survival in patients with APL according to platelets.

Макед. фарм. билт., 67 (1) 55 - 66 (2021) 
Cumulative Proportion Surviving (Kaplan-Meier)

- Complete + Censored

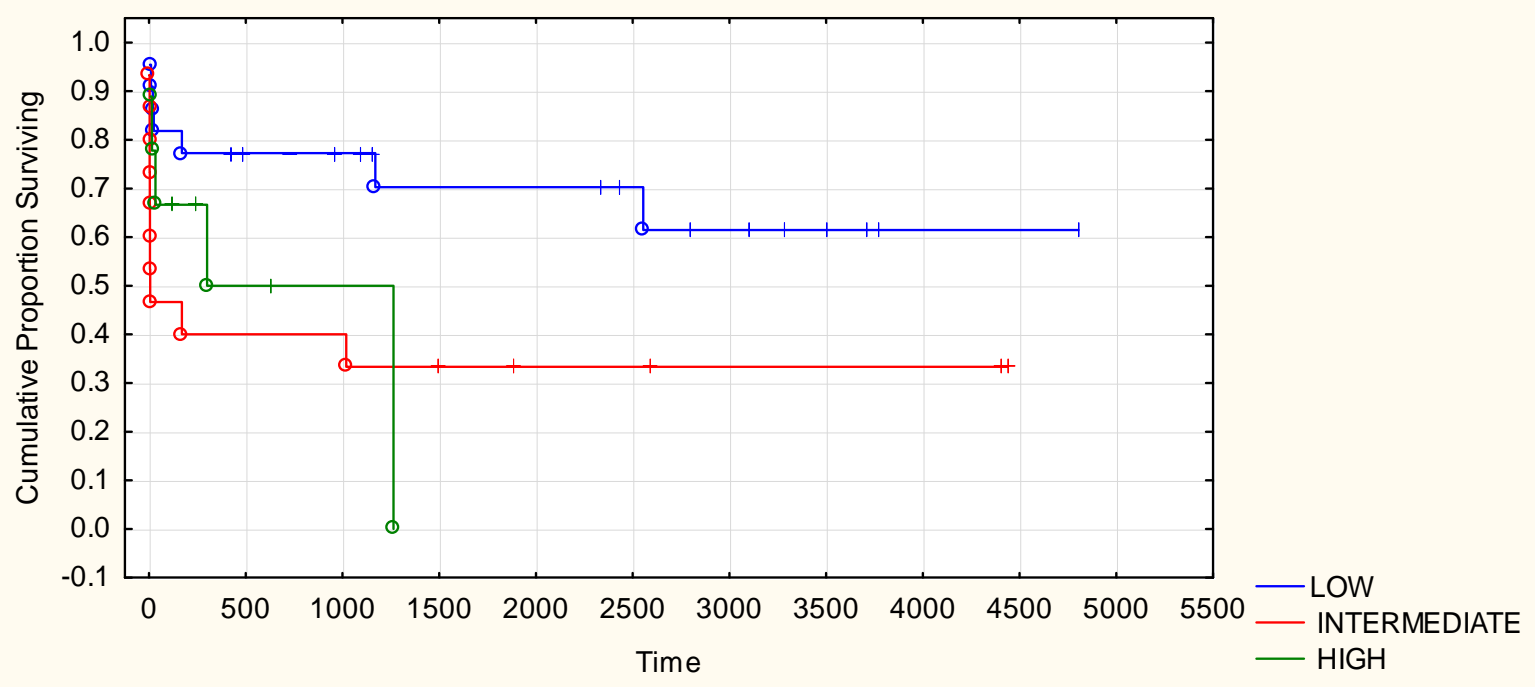

Fig. 5. Overall survival according to Sanz risk in APL

We report early death in $59.1 \%$ of our patients. This high rate could be probably a result of delayed supportive treatment, late visit to a doctor and appropriate medical experience care. In some cases, ATRA administration was delayed, because we did not have the confirmed molecular analysis. Some studies have identified prognostic factors that are capable of predicting early deaths.

Regarding the causes of death, the main cause in our study was CNS hemorrhage, followed by infections. These findings correlate with other studies which showed hemorrhage as the main cause of death (Chang et al., 2012; Crespo-Solis et al., 2016; Karim et el., 2014; Rego et al., 2013; Rogers et al., 2012; Serefhanoglu et al., 2010). In our center CNS bleeding was also the major cause of death in $59.1 \%$ of all patients, followed by infections in $18.2 \%$ of patients, and ATRA respiratory and acute renal failure were found in a smaller percentage as a cause of death.

Despite some small center experiences reporting the infections as a main cause of death (Ahmad, et al 2012)., due to the late visit to the hospital, delayed treatment, absence of isolation rooms in the hospital, lack of accurate microbial cultures, inability of patients to afford expensive drugs like antifungals, in our study infections were the second reason of causes of death. Relapse of the disease was not a main cause of death in APL compared to AML.

The limitation of our study is that not all patients with APL have completed induction chemotherapy protocol. During induction, there were 8 patients with early death and two patients during induction and consolidation who died later. Since there was a lack of more aggressive supportive measures and addition of ATO to the induction regimen, patients with high risk of early death were not treated appropriately.
In large population-based analyses, and among patients treated in single institutions, the rate of mortality is even higher and can range from $9.6 \%$ to $61.5 \%$ (Jillella and Kota, 2018). Our observations correlate with the literature data; our mortality rate was $47.8 \%$ of APL patients.

The OS (overall survival) in our group was decreased, we observed that $52.2 \%$ of our patients are alive compared to world studies where OS rates are between $80-90 \%$. As expected, OS was longer in patients who had low Sanz score than patients who had high Sanz score. High levels of WBC and low levels of PL were shown to be risk factors in our study. Younger patients and higher PL levels are a predictive factor that prolonged the OS in our study. Therefore, we must change our approach to APL patients and to start faster and more aggressive treatment once the patient comes to the hospital and is being properly diagnosed.

\section{Conclusion}

To prevent early death prior to treatment, patients with suspected APL should be immediately hospitalized and managed as medical emergency. It is the most important approach in patients with acute leukemia, especially with APL. The diagnosis must be managed even in cases when there is no confirmed molecular PMLRAR $\alpha$ fusion. In this kind of situation, it is necessary to initiate aggressive prophylactic transfusion in order to maintain high platelet and fibrinogen transfusions. This could reduce bleeding complications which is the main reason for ED. Induction chemotherapy should be started as soon as possible, treatment with ATRA should be 
Table 6. Results of Log-Rank Test from survival comparison between two groups of patients (WBC $\geq 10 \times 109 / \mathrm{L}$ and $<10$ $\mathrm{x}$ 109/L)

\begin{tabular}{|c|c|c|c|c|c|c|c|c|}
\hline \multirow{4}{*}{ WBC } & \multicolumn{8}{|c|}{ Means and Medians for Survival Time } \\
\hline & \multicolumn{4}{|c|}{ Mean $^{a}$} & \multicolumn{4}{|c|}{ Median } \\
\hline & \multirow{2}{*}{ Estimate } & \multirow{2}{*}{ Std. Error } & \multicolumn{2}{|c|}{ 95\% Confidence Interval } & \multirow{2}{*}{ Estimate } & \multirow{2}{*}{ Std. Error } & \multicolumn{2}{|c|}{ 95\% Confidence Interval } \\
\hline & & & Lower Bound & Upper Bound & & & Lower Bound & Upper Bound \\
\hline$<10 \times 10^{9} / \mathrm{L}$ & 2821.814 & 437.208 & 1964.886 & 3678.743 & . & & . & . \\
\hline$\geq 10 \times 10^{9} / \mathrm{L}$ & 1561.333 & 529.448 & 523.615 & 2599.052 & 6.000 & 80.186 & .000 & 163.164 \\
\hline Overall & 2466.774 & 354.602 & 1771.755 & 3161.794 & 2555.000 & & & \\
\hline
\end{tabular}

Table 7. Results of Log-Rank Test from survival comparison between two groups of patients (PL >30-low risk and PL $<30$-high risk)

\begin{tabular}{|c|c|c|c|c|c|c|c|c|}
\hline \multirow{4}{*}{ PL } & \multicolumn{8}{|c|}{ Means and Medians for Survival Time } \\
\hline & \multicolumn{4}{|c|}{ Mean $^{\mathrm{a}}$} & \multicolumn{4}{|c|}{ Median } \\
\hline & \multirow{2}{*}{ Estimate } & \multirow{2}{*}{ Std. Error } & \multicolumn{2}{|c|}{ 95\% Confidence Interval } & \multirow{2}{*}{ Estimate } & \multirow{2}{*}{ Std. Error } & \multicolumn{2}{|c|}{ 95\% Confidence Interval } \\
\hline & & & Lower Bound & Upper Bound & & & Lower Bound & Upper Bound \\
\hline Low & 577.617 & 176.196 & 232.273 & 922.961 & & . & . & . \\
\hline High & 2845.533 & 400.035 & 2061.465 & 3629.601 & 300.000 & 385.127 & .000 & 1054.849 \\
\hline Overall & 2466.774 & 354.602 & 1771.755 & 3161.794 & 2555.000 & . & . & . \\
\hline
\end{tabular}

Table 8. Results of Log-Rank Test from survival comparison between three groups of patients according to Sanz score

\begin{tabular}{|c|c|c|c|c|c|c|c|c|}
\hline \multirow{4}{*}{ Sanz score } & \multicolumn{8}{|c|}{ Means and Medians for Survival Time } \\
\hline & \multicolumn{4}{|c|}{ Mean $^{\mathrm{a}}$} & \multicolumn{4}{|c|}{ Median } \\
\hline & \multirow{2}{*}{ Estimate } & \multirow{2}{*}{ Std. Error } & \multicolumn{2}{|c|}{ 95\% Confidence Interval } & \multirow{2}{*}{ Estimate } & \multirow{2}{*}{ Std. Error } & \multicolumn{2}{|c|}{ 95\% Confidence Interval } \\
\hline & & & Lower Bound & Upper Bound & & & Lower Bound & Upper Bound \\
\hline high & 688.222 & 235.240 & 227.152 & 1149.292 & 300.000 & 344.075 & .000 & 974.387 \\
\hline low & 3270.486 & 472.923 & 2343.557 & 4197.414 & . & . & . & . \\
\hline intermedia. & 1561.333 & 529.448 & 523.615 & 2599.052 & 6.000 & 80.186 & .000 & 163.164 \\
\hline Overall & 2466.774 & 354.602 & 1771.755 & 3161.794 & 2555.000 & . & . & . \\
\hline
\end{tabular}


started immediately even if the diagnosis of APL is only suspected. These elements should be considered at our Center in order to improve the overall survival and consequently to decrease the early death rates which is the greatest challenge for the future treatment of APL.

\section{References}

Ahmad, E.I., Akl, H., Hashem, M.E., Elgohary, T.A.M., 2012. The biological characteristics of adult CD34+ acute promyelocytic leukemia. Medical Oncology 29(2), 11191126. Available at: https://doi.org/10.1007/s12032-0119895-y.

Albano, F., Mestice, A., Pannunzio, A., Lanza, F., Martino, B., Pastore, D., Ferrara, F., Carluccio, P., Nobile, F., Castoldi, G., Liso, V., Specchiaet, G., 2006. The biological characteristics of CD34+ CD2+ adult acute promyelocytic leukemia and the CD34- CD2- hypergranular (M3) and microgranular (M3v) phenotypes. Haematologica 91(3), 311-316.

Asou, N., Adachi, K., Tamura, J., Kanamaru, A., Kageyama, S., Hiraoka, A., Omoto, E., Hideki, A., Tsubaki, K., Saito, K., Kuriyama, K., Oh, H., Kitano, K., Miyawaki, S., Takeyama, K., Yamada, O., Nishikawa, K., Takahashi, M., Matsuda, S., Ohtake, S., Ohno, R., 2001. Analysis of prognostic factors in newly diagnosed patients with acute promyelocytic leukemia: the APL92 study of the Japan Adult Leukemia Study Group (JALSG). Cancer Chemother. Pharmacol. 48(Suppl1), S65-71. Available at: https://doi.org/10.1007/s002800100308.

Bennett, J.M., Catovsky, D., Daniel, M.T., Flandrin. G., Galton, D.A., Gralnick, H.R., Sultan, C., 1976. Proposals for the classification of the acute leukaemias. French-AmericanBritish (FAB) co-operative group. Br. J. Haematol. 33(4), 451-458. Available at: https://doi.org/10.1111/j.13652141.1976.tb03563.x.

Bernard, J., Weil, M., Boiron, M., Jacquillat, C., Flandrin, G., Marie-François, G., 1973. Acute promyelocytic leukemia: results of treatment by daunorubicin. Blood 41, 489-496. Available at: https://doi.org/10.1182/blood.V41.4.489.489.

Chang, H., Kuo, M.C., Shih, L.Y., Dunn, P., Wang, P.N., Wu, J.H., Lin, T.L., Hung, Y.S., Tang, T.C., 2012. Clinical bleeding events and laboratory coagulation profiles in acute promyelocytic leukemia. Eur. J. Haematol. 88, 321328. Available at: https://doi.org/10.1111/j.1600-0609.2011.01747.x.

Choudhry, A., DeLoughery, T.G., 2012. Bleeding and thrombosis in acute promyelocytic leukemia. Am. J. Hematol. 87, 596-603. Available at: https://doi.org/10.1002/ajh.23158.

Contreras-Cisneros, J., Crespo-Solis, E., Demichelis-Gomez, R., Rosas-Lopez, A., Vera-Zertuche, J.M., Aguayo, A., López-Karpovitch, Xavier, 2016. Survival and treatment response in adults with acute promyelocytic leukemia treated with a modified International Consortium on Acute Promyelocytic Leukemia protocol. Rev. Bras. Hematol. Hemoter. 38, 285-290. Available at: https://doi.org/10.1016/j.bjhh.2016.08.002.

Daver, N., Kantarjian, H., Marcucci, G., Pierce, S., Brandt, M., Dinardo, C., Pemmaraju, N., Garcia-Manero, G., O'Brien, S., Ferrajoli, A., Verstovsek, S., Popat, U., Hosing, C.,
Anderlini, P., Borthakur, G., Kadia, T., Cortes, J., Ravandi, F., 2015. Clinical characteristics and outcomes in patients with acute promyelocytic leukaemia and hyperleucocytosis. Br. J. Haematol. 168, 646-653. Available at: https://doi.org/10.1111/bjh.13189.

De Thé, H., Le Bras, M., Lallemand-Breitenbach, V., 2012. The cell biology of disease: acute promyelocytic leukemia, arsenic, and PML bodies. J. Cell Biol. 198, 11-21. Available at: https://doi.org/10.1083/jcb.201112044.

Iland, H.J., Bradstock, K., Supple, S.G., Catalano, A., Collins, M., Hertzberg, M., Browett, P., Grigg, A., Firkin, F., Hugman, A., Reynolds, J., Di Iulio, J., Tiley, C., Taylor, K., Filshie, R., Seldon, M., Taper, J., Szer, J., Moore, J., Bashford, J., Seymour, J.F., 2012. Australasian Leukaemia and Lymphoma Group. All-trans-retinoic acid, idarubicin, and IV arsenic trioxide as initial therapy in acute promyelocytic leukemia (APML4). Blood 120(8), 15701580. Available at: https://doi.org/10.1182/blood-201202-410746.

Jillella, A.P., Kota, V.K., 2018. The global problem of early deaths in acute promyelocytic leukemia: a strategy to decrease induction mortality in the most curable leukemia. Blood 32, 89-95. Available at: https://doi.org/10.1016/j.blre.2017.09.001.

Karim, F., Shaikh, U., Adil, S.N., Khurshid, M., 2014. Clinical characteristics, outcome and early induction deaths in patients with acute promyelocytic leukaemia: a five-year experience at a tertiary care centre. Singapore Med. J. 55, 443-447. Available at: http://dx.doi.org/10.11622/smedj.2014105.

Lo-Coco, F., Avvisati, G., Vignetti, M., Thiede, C., Orlando, S., Iacobelli, S., Ferrara, F., Fazi, P., Cicconi, L., Bona, E., Specchia, G., Sica, S. Divona, M., Levis, A., Fiedler, W., Cerqui, E., Breccia, M., Fioritoni, G., Salih, H., Platzbecker, U., 2013. Retinoic acid and arsenic trioxide for acute promyelocytic leukemia. N. Engl. J. Med. 369, 111-21. Available at: https://doi.org/10.1056/NEJMoa1300874.

Park, J.H., Qiao, B., Panageas, K.S., Schymura, M.J., Jurcic, J.G., Rosenblat, T.L., Altman, J.K., Douer, D., Rowe, J.M., Tallman, M.S, 2011. Early death rate in acute promyelocytic leukemia remains high despite all-trans retinoic acid. Blood 118, 1248-1254. Available at: https:// doi.org/10.1182/blood-2011-04-346437.

Paulson, K., Serebrin, A., Lambert, P., Bergeron, B., Everett, J., Kew, A., Jones, D., Mahmud, S., Meloche, C., Sabloff, M., Sharif, I., Storring, J., Turner, D., Seftel, M.D., 2014. Acute promyelocytic leukemia is characterized by stable incidence and improved survival that is restricted to patients managed in leukemia referral centers: a panCanadian epidemiological study. Br. J. Haematol. 166, 660-666. Available at: https://doi.org/10.1111/bjh.12931.

Rahmé, R., Thomas, X., Recher, C., Vey, N., Delaunay, J., Deconinck, E., Hirsch, P., Bordessoule, D., Micol, J.B., Stamatoullas, A., Mariette, C., Pautas, C., Bories, P., Marolleau, J.P., Hunault-Berger, M., Fegueux, N., Raffoux, E., Dombret, H., Degos, L., Fenaux, P., Adès., L., 2014. Early death in acute promyelocytic leukemia (APL) in French centers: a multicenter study in 399 patients. Leukemia 28, 2422-2424. Available at: https://doi.org/10.1038/leu.2014.240.

Rego, E.M., De Santis, G.C., 2011. Differentiation syndrome in promyelocytic leukemia: clinical presentation, 
pathogenesis and treatment. Mediterranean Journal of Hematology and Infectious Diseases 3(1), e2011048. Available at: https://doi.org/10.4084/mjhid.2011.048.

Rego, E.M., Kim, H.T., Ruiz-Arguelles, G.J., Undurraga, M.S., Uriarte del, R., Jacomo, R.H., Gutiérrez-Aguirre, H., Melo, R.A.M., Bittencourt, R., Pasquini, R., Pagnano, K., Fagundes, E.M., de Lourdes Chauffaille, M., Chiattone, C.S., Martinez, L., Meillón, L.A., Gómez-Almaguer, D., Kwaan, H.C., Garcés-Eisele, J., Gallagher, R., Niemeyer, C.M., Schrier, S.L., Tallman, M., Grimwade, D., Ganser, A., Berliner, N., Ribeiro, R.C., Lo-Coco, F., Löwenberg, B., Sanz., M.A., 2013. Improving acute promyelocytic leukemia (APL) outcome in developing countries through networking, results of the International Consortium on APL. Blood 121, 1935-1943. Available at: https://doi.org/10.1182/blood-2012-08-449918.

Rogers, J.E., Yang, D., 2012. Differentiation syndrome in patients with acute promyelocytic leukemia. J. Oncol. Pharm. Pract. 18, 109-14. Available at: https://doi.org/10.1177/1078155211399163.

Sant, M., Allemani, C., Tereanu, C., De Angelis, R., Capocaccia, R., Visser, O., Marcos-Gragera, R., Maynadié, M., Simonetti, A., Lutz, J.M., Berrino, F., HAEMACARE Working Group, 2010. Incidence of hematologic malignancies in Europe by morphologic subtype: results of the HAEMACARE project. Blood 116(19), 3724-3734. Available at: https://doi.org/10.1182/blood-2010-05282632.

Sanz, M.A., Fenaux, P., Tallman, M.S., Estey, E.H., Löwenberg, B., Naoe, T., Lengfelder, E., Döhner, H., Burnett, A.K., Chen, S.J., Mathews, V., Iland, H., Rego, E., Kantarjian, H., Adès, L., Avvisati, G., Montesinos, P., Platzbecker, U., Ravandi, F., Russell, N.H., Lo-Coco, F., 2019. Management of acute promyelocytic leukemia: updated recommendations from an expert panel of the European LeukemiaNet. Blood 133(15), 1630-1643. Available at: https://doi.org/10.1182/blood-2019-01-894980.

Sanz, M.A., Lo Coco, F., Martin, G., Avvisati, G., Rayon, C., Barbui, T., Díaz-Mediavilla, J., Fioritoni, G., González, J.D., Liso, V., Esteve, J., Ferrara, F., Bolufer, P., Bernasconi, C., Gonzalez, M., Rodeghiero, F., Colomer, D., Petti, M.C., Ribera, J.M., Mandelli, F., 2000. Definition of relapse risk and role of nonanthracycline drugs for consolidation in patients with acute promyelocytic leukemia: a joint study of the PETHEMA and GIMEMA cooperative groups. Blood 96,1247-1253. Available at: https://doi.org/10.1182/blood.V96.4.1247.

Sanz, M.A., Montesinos, P., Vellenga, E., Rayón, C., de la Serna, J., Parody, R., Bergua, J.M., León, A., Negri, S., González, M., Rivas, C., Esteve, J., Milone, G., González, J.D., Amutio, E., Brunet, S., García-Laraña, J., Colomer, D., Calasanz, M.J., Chillón, C., Barragán, E., Bolufer, P., Lowenberg, B., 2008. Risk-adapted treatment of acute promyelocytic leukemia with all-trans retinoic acid and anthracycline monochemotherapy: long-term outcome of the LPA 99 multicenter study by the PETHEMA Group. Blood 112(8), 3130-3134. Available at: https://doi.org/10.1182/blood-2008-05-159632.

Sanz, M.A., Montesinos, P., Rayón, C., Holowiecka, A., De la Serna, J., Milone, G., De Lisa, E., Brunet, S., Rubio, V., Ribera, J.M., Rivas, C., Krsnik, I., Bergua, J., González, J.,
Díaz-Mediavilla, J., Rojas, R., Manso, F., Ossenkoppele, G., González, J.D., Lowenberg, B. on behalf of the PETHEMA and HOVON Groups, 2010. Risk-adapted treatment of acute promyelocytic leukemia based on alltrans retinoic acid and anthracycline with addition of cytarabine in consolidation therapy for high-risk patients: further improvements in treatment outcome. Blood 115(25), 5137-5146. Available at: https://doi.org/10.1182/blood2010-01-266007

Serefhanoglu, S., Buyukasik, Y., Goker, H., Sayinalp, N., Haznedaroglu, I.C., Aksu, S., OZcebe, O.I., Turgut, M., Aslan, R., Ozdemir, E., 2010. Clinical features and outcomes of 49 Turkish patients with acute promyelocytic leukemia who received ATRA and anthracyclines (PETHEMA protocol) therapy. Leuk. Res. 34, e317-9. Available at: https://doi.org/10.1016/j.leukres.2010.07.027.

Siddikuzzaman, G.C., Berlin Grace, V.M., 2011. All trans retinoic acid and cancer. Immunopharmacology and immunotoxicology 33(2), 241-249. Available at: https://doi.org/10.3109/08923973.2010.521507.

Tallman, M.S., Andersen, J.W., Schiffer, C.A., Appelbaum, F.R., Feusner, J.H., Ogden, A., Shepherd, L., Willman, C., Bloomfield, C.D., Rowe, J.M., Wiernik, P.H., 1997. Alltrans-retinoic acid in acute promyelocytic leukemia. N. Engl. J. Med. 337(15), 1021-1028. Available at:

https://doi.org/10.1056/nejm199710093371501.

Thomas, X., 2019. Acute Promyelocytic Leukemia: A History over 60 Years - From the Most Malignant to the most Curable Form of Acute Leukemia. Oncol. Ther. 7, 33-65. Available at: https://doi.org/10.1007/s40487-018-0091-5.

Vardiman, J.W., Thiele, J., Arber, D.A., Brunning, R.D., Borowitz, M.J., Porwit, A., Harris, N.L., Le Beau, M.M., Hellström-Lindberg, E., Tefferi, A., Bloomfield, C.D., 2009. The 2008 revision of the World Health Organization (WHO) classification of myeloid neoplasms and acute leukemia: rationale and important changes. Blood 114(5), 937-951. Available at: https://doi.org/10.1182/blood-200903-209262.

Wang, Z.Y., Chen, Z., 2008. Acute promyelocytic leukemia: from highly fatal to highly curable. Blood 111(5), 25052515. Available at: https://doi.org/10.1182/blood-2007-07102798 .

Watts, J.M., Tallman, M.S., 2014. Acute promyelocytic leukemia: what is the new standard of care? Blood 28(5), 205-212. Available at: https://doi.org/10.1016/j.blre.2014.07.001.

Xu. F., Yin, C.X., Wang, C.L., Jiang, X.J., Jiang, L., Wang, Z.X., Yi, Z.S., Huang, K.K., Meng, F.Y., 2014. Immunophenotypes and Immune Markers Associated with Acute Promyelocytic Leukemia Prognosis. Disease Markers, 2014, Article ID 421906. Available at: https://doi.org/10.1155/2014/421906.

Yanada, M., Matsushita, T., Asou, N., Kishimoto, Y., Tsuzuki, M., Maeda, Y., Horikawa, K., Okada, M., Ohtake, S., Yagasaki, F., Matsumoto, T., Kimura, Y., Shinagawa, K., Iwanaga, M., Miyazaki, Y., Ohno, R., Naoe, T., 2007. Severe hemorrhagic complications during remission induction therapy for acute promyelocytic leukemia: incidence, risk factors, and influence on outcome. European Journal of Haematology 78, 213-219. Available at: https://doi.org/10.1111/j.1600-0609.2006.00803.x. 


\title{
Резиме
}

\section{Рана смртност и вкупно преживување кај акутна промиелоцитна леукемија - искуство на еден центар}

\author{
Светлана Крстевска Балканов ${ }^{1 *}$, Сања Трајкова ${ }^{1}$, Соња Генадиева Ставриќ ${ }^{1}$, \\ Александра Пивкова Велјановска ${ }^{1}$, Симона Стојановска ${ }^{1}$, Дејан Спасовски ${ }^{2}$, \\ Божидар Кочоски ${ }^{1}$, Ирина Пановска Ставридис ${ }^{1}$ \\ ${ }^{1}$ Универзитетска клиника за хематологија, Медицински факултет, \\ Универзитет „Св. Кирил и Методиј“, Мајка Тереза 17, \\ 1000 Скопје, Република Северна Македонија \\ ${ }^{2}$ Универзитетска клиника за ревматологија, Медицински факултет, Универзитет \\ „Св. Кирил и Методиј“, Мајка Тереза 17, \\ 1000 Скопје, Република Северна Македонија
}

Клучни зборови: акутна промиелоцитна леукемија, рана смртност, all-trans ретиноична киселина

Акутна промиелоцитна леукемија (АПЛ) е посебен поттип на акутна леукемија (АЛ) со своја различна цитогенетика, клинички и биолошки карактеристики, и со најбрз летален исход. Со примената на новите таргет лекови како all-trans ретиноична киселина (AТРА) стана најкурабилна форма на АЛ.

Сѐ уште раната смртност дефинирана како смрт во период од триесет дена по дијагноза останува нерешлив проблем кај пациентите со АПЛ. Оваа студија анализираше 46 пациенти со АПЛ, дијагностицирани и лекувани на Универзитетската клиника за хематологија во Скопје, од јануари 2004 до декември 2020 година. АПЛ дијагнозата на пациентите беше спроведена според FAB и WHO класификации, и беше потврдена на молекуларно ниво кај сите пациенти. Користевме утврдени прогностички ризик-фактори при анализата на пациентите: возраста, Sanz score, иницијалното ниво на леукоцити и тромбоцити, клиничката презентација на болеста и нивото на фибриноген и Д-димери. Ја утврдивме појавата на рана смртност, стапката на морталитет и вкупното преживување. Од групата со рана смртност, одреден број пациенти имаа летален исход и пред почнување со хемотерапискиот пристап. Беше анализирана и причината за смртност во целата група пациенти. Студијата покажа дека факторите кои влијааат врз појавата на рана смртност влијаат и врз стапката на морталитет како и врз вкупното преживување. Имплементацијата на ризик-факторите во донесување одлука за третман заедно со брзиот агресивен супортивен третман се клучни за нашите пациенти со АПЛ. 